\title{
Critical Role of Computer Simulations in Teaching and Evaluating Thermal and Energy System Courses
}

\section{Dr. Kendrick T. Aung, Lamar University}

KENDRICK AUNG is a professor in the Department of Mechanical Engineering at Lamar University. He received his Ph.D. degree in Aerospace Engineering from University of Michigan in 1996. He is an active member of ASEE, ASME, AIAA and SAE. He has published over 80 technical papers and presented several papers at national and international conferences.

\section{Dr. Jiang Zhou, Lamar University}

Dr. Jiang Zhou is currently a professor with the Department of Mechanical Engineering at Lamar University, Beaumont, Texas. She received her Ph. D. in Mechanical Engineering from the University of Maryland at Baltimore County (UMBC), Baltimore, Maryland, in 2003. Her research interests include mechanical applications in microelectronics, biomechanics, system dynamics, and system optimizations, etc. 


\title{
Critical Role of Computer Simulations in Teaching and Evaluating Thermal and Energy System Courses
}

\begin{abstract}
Modeling and simulation exercises are an important component of engineering education. The main benefit of simulation exercises for engineering students lies in numerical experimentation of the model that can determine an operational envelope of components such as a heat exchanger or systems such as a gas turbine. The objective of the paper is to evaluate effectiveness and efficacy of modeling and simulations projects that are being used in two courses: Design of Thermal Systems and Energy Engineering. Both direct method of assessment, performance indicators for student learning outcomes, and an indirect method of assessment, student survey, are used to determine effectiveness and efficacy of modeling and simulations projects.
\end{abstract}

\section{Introduction}

Modeling and simulation exercises are an important component of engineering education. Jaluria states in his book ${ }^{1}$ that modeling is one of the most crucial elements in the design and optimization of thermal systems. In thermal and energy system courses, design of a heat exchanger or solution of a piping network are common exercises assigned to the students as open-ended projects or design problems. However, the majority of these exercises is still limited to obtaining a single satisfactory solution. In reality, most of the thermal systems rarely operates at the design conditions, rather at a variety of inputs and operating parameters such as flow rates and temperature. As a result, modeling and simulation of these system are required in order to predict and understand characteristics of the system under varying conditions.

Due to the importance of modeling and simulation in engineering education, several papers ${ }^{2-6}$ addressed uses and benefits of simulation in teaching thermal and energy systems. The authors integrated simulation projects in two courses to provide students exposure and experience of mathematical modeling and computer solution of mathematical models. The main benefit of these simulation exercises for engineering students lies in numerical experimentation of the model that can determine an operational envelope of components such as a heat exchanger or systems such as a gas turbine.

\section{Objective}

The objective of the paper is to evaluate effectiveness and efficacy of modeling and simulations projects that are being used in two courses: Design of Thermal Systems and Energy Engineering, Design of Thermal Systems course is a required course for seniors whereas Energy Engineering course is an elective course for senior students. In Design of Thermal Systems course, two simulation projects, one on piping systems and another on power systems such as a land-based gas turbine system or an IC engine of an automobile, are used for this paper. In Energy Engineering course, a simulation project of renewable energy systems such as solar PV systems and wind farms is used for evaluation purpose. The criteria for evaluation is based on 
the performance indicators of student learning outcomes, ABET outcome (c) and outcome (e). Both direct method of assessment, performance indicators for student learning outcomes, and an indirect method of assessment, student survey, are used to determine effectiveness and efficacy of modeling and simulations projects.

\section{Courses and Outcomes}

MEEN 4313 Design of Thermal Systems is a required course for mechanical engineering senior students and is offered in every fall semester. The course is similar to Capstone design course as it provides culminating experience on design of thermal and energy systems for seniors. The ABET outcomes for the course are

- Outcome (a) "an ability to apply knowledge of mathematics, science, and engineering"

- Outcome (c) "an ability to design a system, component, or process to meet desired needs within realistic constraints such as economic, environmental, social, political, ethical, health and safety, manufacturability, and sustainability"

- Outcome (e) "an ability to identify, formulate, and solve engineering problems"

Using the ABET outcomes, specific course outcomes based on the course topics are developed as follows:

- Select appropriate pumps, fans and compressors based on engineering specifications

- Select appropriate heat exchangers based on engineering specifications

- Perform curve fittings of components of a thermal system such as a pump

- Compute thermal and transport properties to conduct simulations

- Solve systems of non-linear algebraic equations representing models of thermal systems

- Model and simulate thermal systems

More information on the course such as textbook and course contents can be found in an earlier ASEE paper $^{7}$ by the author.

MEEN 4362 Energy Engineering is an elective course for the senior undergraduate students but first-year graduate students are also allowed to take the course. The only ABET outcome for the course is

- Outcome (e) "an ability to identify, formulate, and solve engineering problems"

More information on the course and the simulation tools can be found in earlier ASEE papers ${ }^{8,9}$ by the author.

\section{Assessment Tools and Methodology}

The direct methods of assessment through computer simulation and design projects were used for assessing the ABET outcomes. Two simulation projects in the Design of Thermal System course and a simulation project in the Energy Engineering course were used as the main vehicle for assessing outcome (e). In both courses, simulation projects were completed by a group of students so it should be noted that the assessment results were not applicable to an individual student. 
According to ABET, performance indicators are concrete measurable performances students must meet as indicators of achievements of the outcome ${ }^{10}$. Therefore, performance indicators were developed for each student outcome through a departmental ABET committee and were used for assessment in every course relevant to all engineering courses. Performance indicators for the three student outcomes, outcomes a, c, and e, and corresponding rubric were given in the Appendix A. The scoring for the rubric ranges from 1 to 3 with 1 being unsatisfactory and 3 being excellent. In the Design of Thermal Systems course, two simulation projects, one on piping systems and another on thermal systems such as a land-based gas turbine system or a refrigeration system were used and the results of the assessments for these projects were provided and discussed later in the paper. In Energy Engineering course, a simulation project of renewable energy systems such as solar PV systems and wind farms was used in the assessment of the student outcome e and the results were given and discussed later in the paper.

\section{Description of Computer Simulation Projects}

Two projects of the course, Design of Thermal Systems, were chosen so that completion of the projects could be used to assess whether the students achieved the individual outcome of the course and the degree to which the students achieved the ABET outcome through performance indicators.

The first project was chosen to reinforce the principles of pipe flow through pump selection, and simulation of a pumping system. Different pipe flow problems and projects from fluid textbooks of Munson ${ }^{11}$, Fox ${ }^{12}$, and Hibbeler ${ }^{13}$ were used as projects. The main tasks of the project were

- To generate a system curve of the problem,

- To select a proper pump for the system,

- To develop a mathematical equation for the pump curve, and

- To simulate the system operations under different system parameters such as flow rates and pipe materials.

The second project involved modeling and simulation of power and refrigeration systems such as a gas turbine system or a refrigeration system. All the problems were taken from chapter 6 and projects in the appendix of the book ${ }^{14}$, Design of Thermal Systems by Stoecker that was also the textbook of the course. The main tasks of the project were

- To generate a set of mathematical equations for the complete system,

- To identify the simulation parameters, and

- To conduct simulations of the system under varying conditions

The deliverables of both projects were a technical report and an in-class presentation by the group. The instructor provided sample simulation files of Microsoft Excel and MathCAD files to the students. The students' opinion on the usefulness of these samples files were given later in the paper. 
In the course, Energy Engineering, a project on one of the renewable energy systems, a wind farm or a solar plant, was used as an assessment vehicle. Each group was assigned an actual wind or solar power plant to simulate. System Advisor Model (SAM) software from National Renewable Energy Lab (NREL) was used as the only simulation tool. The main tasks of the project were

- To develop an engineering problem statement using actual engineering specifications of the power plant,

- To formulate the problem in the SAM software,

- To conduct simulations of the system using SAM software, and

- To evaluate the plant performance (including economic analysis) against the actual plant performance data such as total energy generation and levelized cost of energy (LCOE)

The deliverables of the project was a technical report and an in-class presentation by each student group.

\section{Assessment Results}

The results of assessment of two computer simulation projects from Design of Thermal Systems course were given in Table 1. The results were provided in terms of the percentage of the teams that met or exceeded each performance indicator of outcome (e). There were 14 teams that comprised a total of 51 students.

Table 1 Percentage of teams that met or exceeded each performance indicator in two projects of Design of Thermal Systems Course

\begin{tabular}{|l|c|l|}
\hline \multicolumn{1}{|c|}{ Performance Indicator } & \multicolumn{2}{|c|}{ Percentage of teams } \\
\hline $\begin{array}{l}\text { Identify the problem (problem } \\
\text { statement) }\end{array}$ & Project \#1 & Project \#2 \\
\hline $\begin{array}{l}\text { Formulate the problems } \\
\text { (methodology) }\end{array}$ & $71.4 \%$ & $71.4 \%$ \\
\hline $\begin{array}{l}\text { Solve the problem (solution and } \\
\text { discussion) }\end{array}$ & $64.3 \%$ & $85.7 \%$ \\
\hline
\end{tabular}

Table 1 showed the identical results for both projects but the individual results were different for several teams. The assessment results showed that some student teams had found difficulty in defining their problem statement and providing details on the problem formulation. The main reason was that these teams did not provide comprehensive problem statement (lack of some engineering specifications and constrains) and complete solution methodology such as sketch of the problem, theory, and equations as prescribed in the rubric of the first two performance indicators. Nevertheless, most teams achieved the desired final results and gave some discussions on the final results, and hence had the higher percentage in the last performance indicator. 
The results of assessment of the simulation project from Energy Engineering course were given in Table 2. The results were provided in terms of the percentage of the teams that met or exceeded each performance indicator of outcome (e). The number of student teams was 7 that comprised a total of 23 students.

Table 2 Percentage of teams that met or exceeded each performance indicator in the project of Energy Engineering Course

\begin{tabular}{|l|c|}
\hline \multicolumn{1}{|c|}{ Performance Indicator } & Percentage of teams \\
\hline & Project \#3 \\
\hline Identify the problem (problem statement) & $85.7 \%$ \\
\hline Formulate the problems (methodology) & $71.4 \%$ \\
\hline Solve the problem (solution and discussion) & $71.4 \%$ \\
\hline
\end{tabular}

Two out of seven teams did not provide complete problem formulation and did not complete the simulation runs. Therefore, the scores for the last two performance indicators were lower than that of the first performance indicator. The summary of the assessment results of all three projects were shown in Figure 1.

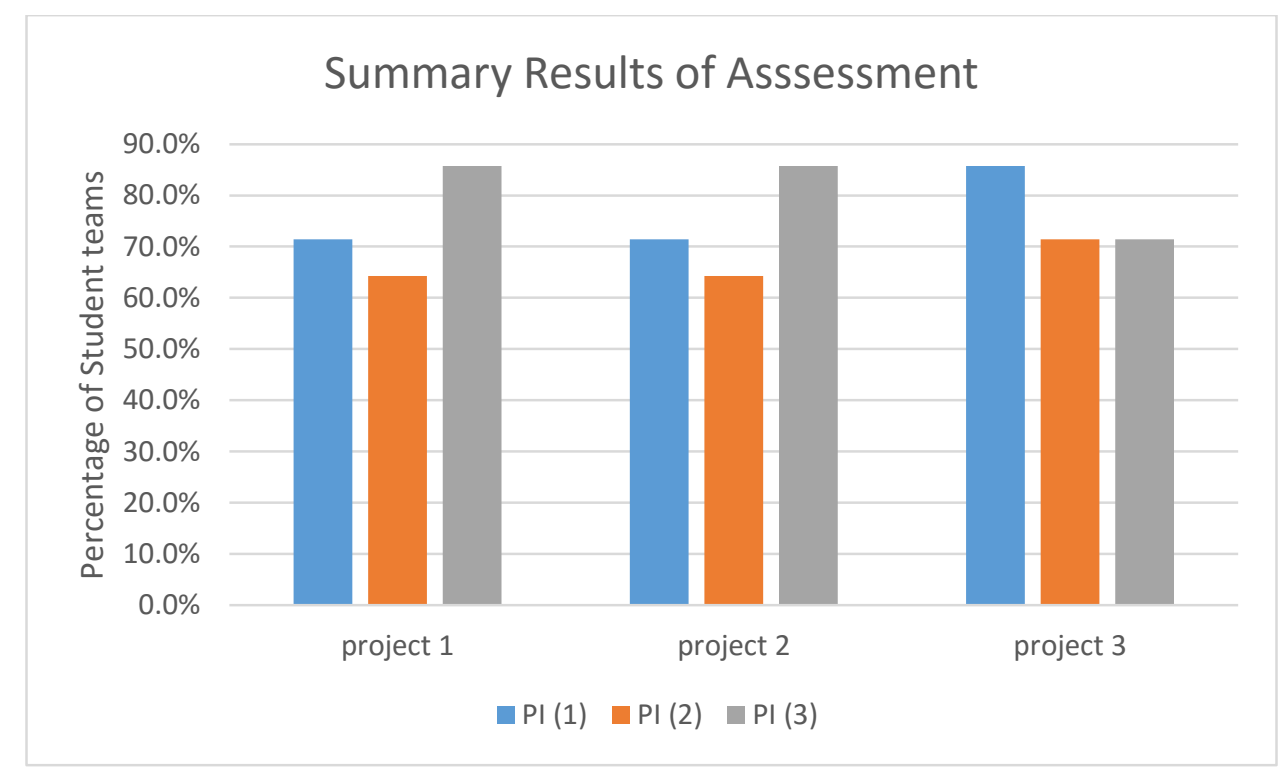

Figure 1 Summary Results of Assessment of Three Projects

The threshold for achieving the satisfactory rating on each performance indicator is $70 \%$ as specified by the departmental ABET committee. The results in Figure 1 shows that there is a need for improvement in satisfactorily achieving each performance indicator of outcome (e). The improvements can be in the form of providing 
- more examples on problem definition including how to identify and include engineering specifications and constraints,

- Additional training on the proper use of the software tools.

\section{Student Survey and Results}

In the Design of Thermal Systems course, an indirect method of assessment, a survey of students, was used to obtain the opinions of students on different aspects of the course: topical importance, attainment of course outcomes, usefulness of simulation and design projects, and helpfulness of computer tools in completing the projects. The survey was included as an appendix of the paper. 42 out of 51 students completed the survey. Rating scales range from 1 to 5 with 5 being the highest. Here, the results of questions relevant only to the paper were given. The results were provided in terms of percentage of students that found the project and the tools useful or very useful. Figure 2 shows the students' rating as a percentage on the individual course outcome. The only outcome directly relevant to the paper was the ability to model and simulate thermal system and $76 \%$ of the students believed that they could perform the task. This result further validated the results using performance indicators as the average rating of all three performance indicators were between $73 \%$ and $75 \%$.

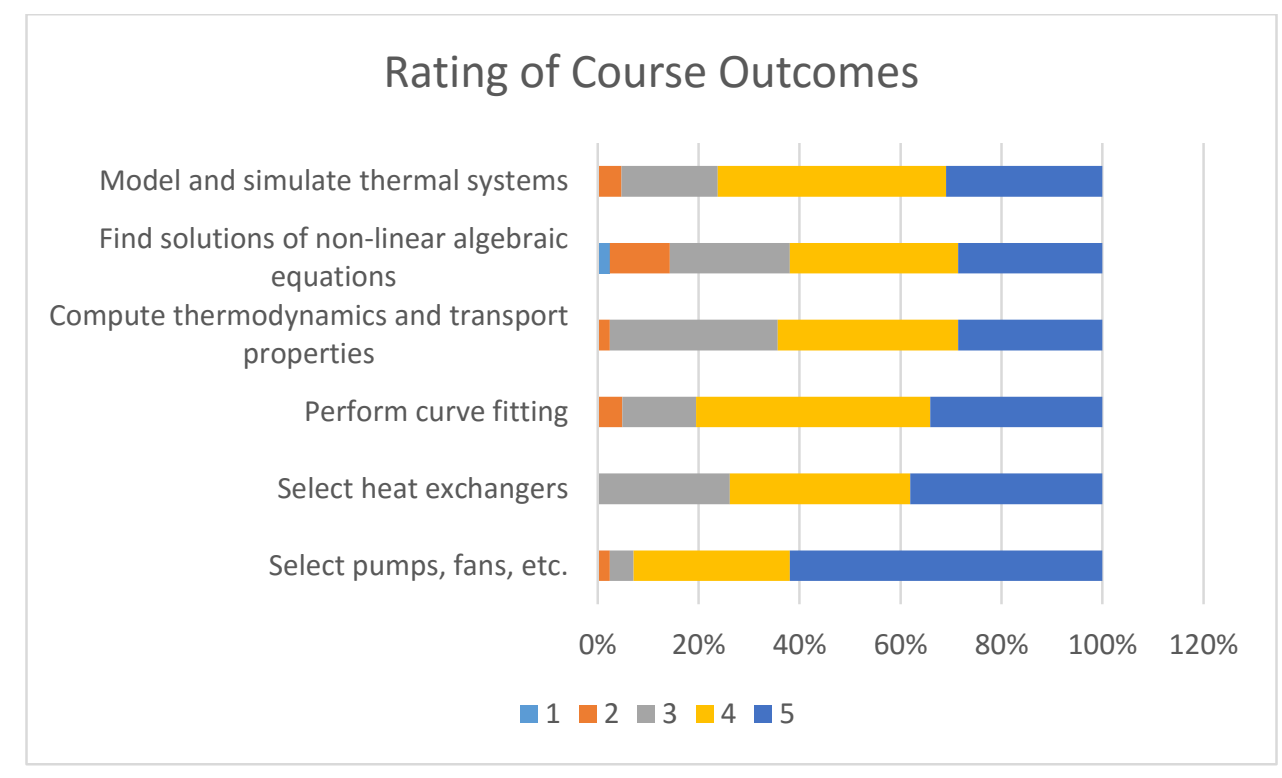

Figure 2 Results of Course Outcome Survey

It should be noted that over $90 \%$ of the students also believed that they could perform selection of pumps that was directly linked to the first project of Design of Thermal Systems course. However, the relatively low ratings of students on the topics of computing the properties and finding solutions of systems of non-algebraic equations showed that they would find difficulty performing these computations manually. On the other hand, these results showed that modern engineering computations and analyses depended heavily on the utilization of computing and 
software tools, and many students had no difficulty performing these computations using engineering tools such as Microsoft Excel. MathCAD and SAM.

The natural consequence of the above discussion led to the evaluation of importance of simulation projects and computing tools. Over $80 \%$ of the students believed that these projects were useful or very useful (ratings 4 and 5) in understanding thermal systems as shown in Figure 3.

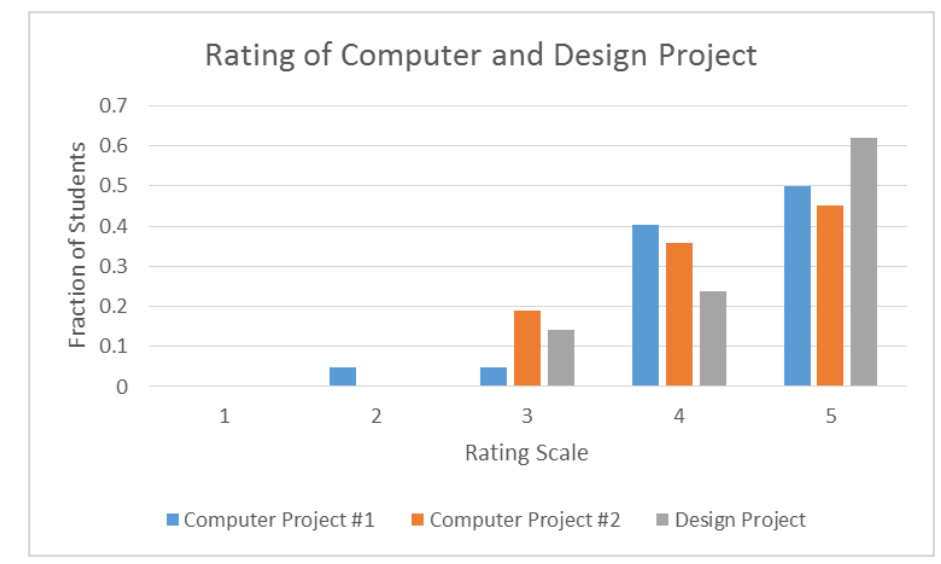

Figure 3 Student Rating of Computer and Design Projects

Similarly, over $80 \%$ of the students believed that the software tools and example files were useful or very useful (ratings 4 and 5) in completing these projects as shown in Figure 4.

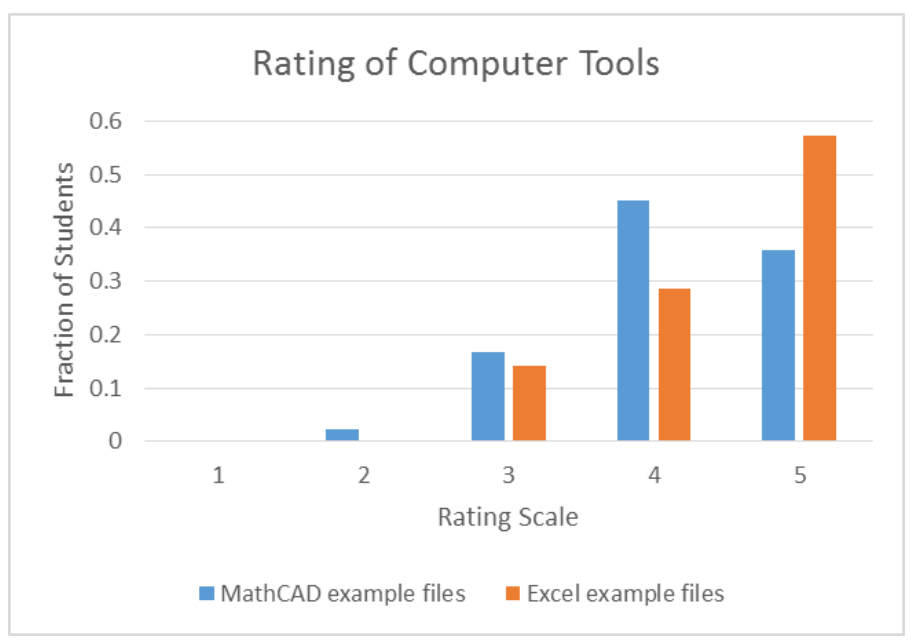

Figure 4 Student Rating of Computer Tools

In summary, the paper gave the results of the assessment of ABET outcome (e) through modeling and simulations projects of thermal and energy systems. Performance indicators were used as a direct method of assessment to evaluate the outcome. The assessed results showed that students in general were able to successfully perform the simulations. However, the assessed results also showed the need for improvements in the aspects of problem identification and 
problem formulation. In addition to direct assessment method, a student survey, an indirect method of assessment, was used to provide an additional measure of the assessment. The survey results showed that over $75 \%$ of students believed they could perform modeling and simulation of thermal and energy systems. Therefore, the survey results further validated the assessment results using performance indicators as the average rating of all three performance indicators were between $73 \%$ and $75 \%$.

\section{Bibliography}

1. Jaluria, Y., Design and Optimization of Thermal Systems, $2^{\text {nd }}$ edition, CRC Press, 2007.

2. Sexton, M. (1999, June), Gas Turbine Engine Simulation Using Mathcad: A Student Project Paper presented at 1999 Annual Conference, Charlotte, North Carolina. https://peer.asee.org/7690

3. Sexton, M. (2004, June), Teaching Energy System Design Using Computer Simulation Paper presented at 2004 Annual Conference, Salt Lake City, Utah. https://peer.asee.org/13269

4. Somerton, C. W. (2012, June), A Computer Simulation Project on Underground Heat Pumps Paper presented at 2012 ASEE Annual Conference, San Antonio, Texas. https://peer.asee.org/20791

5. Peuker, J. M., \& Peuker, S. (2013, June), Incorporating Active Learning into a Thermal System Design Lecture Paper presented at 2013 ASEE Annual Conference, Atlanta, Georgia. https://peer.asee.org/19741

6. Ray, B. (2014, June), Designing Hybrid Energy Storage Systems: A Tool for Teaching System-Level Modeling and Simulation Paper presented at 2014 ASEE Annual Conference, Indianapolis, Indiana. https://peer.asee.org/20269

7. K. Aung, "Design of Thermal Systems: A Lost Course," Proceedings of 2007 ASEE Annual Meeting \& Exposition, Honolulu, Hawaii, June 2007

8. K. Aung, "Energy Engineering: A New Elective for Mechanical Engineering," Proceedings of the 2004 ASEE Annual Meeting \& Exposition, Salt Lake City, Utah, June 2004

9. K. Aung, "Design Exercises and Projects for Energy Engineering," Proceedings of the 2005 ASEE Annual Meeting \& Exposition, Portland, Oregon, June 2005

10. Fundamentals of Program Assessment workshop, Dallas, 2015

11. Munson, B. R., Rothmayer, A. P., Okiishi, T. H., and Huebsch, W. W., Fundamentals of Fluid Mechanics, 7th edition, John Wiley \& Sons, 2012

12. Fox, R. W., McDonald, A. T., and Pritchard, P. J., Introdution to Fluid Mechanics, $6^{\text {th }}$ edition, John Wiley \& Sons, 2003

13. Hibbeler, R. C., Fluid Mechanics, $1^{\text {st }}$ edition, Pearson, 2014.

14. Stoecker, W. F., Design of Thermal Systems, 3rd Edition, McGraw Hill, 1989. 


\section{Appendix A}

Outcome (a): Demonstrate and apply knowledge of mathematics, science and engineering Outcome (c): Design a system, component, or process to meet desired needs within realistic constraints such as economic, environmental, social, political, ethical, health and safety, manufacturability, and sustainability

Outcome (e): Identify, formulate and solve engineering problem

Assessment tools: Quizzes, Exams, Projects

Rating: 1 to 3

Performance Indicators and Rubric for Outcome (a): Demonstrate and apply knowledge of mathematics, science and engineering

Outcome (a): Demonstrate and apply knowledge of mathematics, science and engineering

\begin{tabular}{|c|c|c|c|}
\hline & $\begin{array}{c}\text { Excellent } \\
3\end{array}$ & $\begin{array}{c}\text { Satisfied } \\
2\end{array}$ & $\begin{array}{c}\text { Unsatisfied } \\
1\end{array}$ \\
\hline $\begin{array}{l}\text { Perform } \\
\text { mathematical } \\
\text { principles in } \\
\text { problem solving }\end{array}$ & $\begin{array}{l}\text { Demonstrate effective and } \\
\text { correct use of mathematical } \\
\text { knowledge such as linear } \\
\text { algebra, differential } \\
\text { equations, and numerical } \\
\text { methods. }\end{array}$ & $\begin{array}{l}\text { Mathematical } \\
\text { analysis can be } \\
\text { performed but may } \\
\text { contain errors or } \\
\text { incorrect use. }\end{array}$ & $\begin{array}{l}\text { Essential } \\
\text { mathematical } \\
\text { analysis is missing } \\
\text { or the analysis } \\
\text { contains major } \\
\text { mistakes. }\end{array}$ \\
\hline $\begin{array}{l}\text { Apply scientific } \\
\text { principles in } \\
\text { problem solving }\end{array}$ & $\begin{array}{l}\text { Demonstrate effective and } \\
\text { correct use of physics or } \\
\text { chemistry principles such } \\
\text { as work, power, chemical } \\
\text { equation, etc. }\end{array}$ & $\begin{array}{l}\text { Principles of } \\
\text { physics or chemistry } \\
\text { can be applied but } \\
\text { may contain errors } \\
\text { or incorrect use. }\end{array}$ & $\begin{array}{l}\text { Essential use of } \\
\text { physics or } \\
\text { chemistry principles } \\
\text { is missing or } \\
\text { contains major } \\
\text { mistakes. }\end{array}$ \\
\hline $\begin{array}{l}\text { Apply engineering } \\
\text { knowledge or } \\
\text { theories in } \\
\text { problem solving }\end{array}$ & $\begin{array}{l}\text { Demonstrate effective and } \\
\text { correct use of engineering } \\
\text { theories from mechanisms, } \\
\text { design of machine elements } \\
\text { fluid mechanics, } \\
\text { thermodynamics, heat } \\
\text { transfer, etc. }\end{array}$ & $\begin{array}{l}\text { Engineering } \\
\text { theories from key } \\
\text { subjects can be } \\
\text { applied but may } \\
\text { contain errors or } \\
\text { incorrect use. }\end{array}$ & $\begin{array}{l}\text { Essential use of } \\
\text { engineering theories } \\
\text { is missing or } \\
\text { contains major } \\
\text { mistakes. }\end{array}$ \\
\hline
\end{tabular}


Performance Indicators and Rubric for Outcome (c): Design a system, component, or process to meet desired needs within realistic constraints such as economic, environmental, social, political, ethical, health and safety, manufacturability, and sustainability

Outcome (c): Design a system, component, or process to meet desired needs within realistic constraints such as economic, environmental, social, political, ethical, health and safety, manufacturability, and sustainability

\begin{tabular}{|c|c|c|c|}
\hline & $\begin{array}{c}\text { Excellent } \\
3\end{array}$ & $\begin{array}{c}\text { Satisfied } \\
2\end{array}$ & $\begin{array}{c}\text { Unsatisfied } \\
1\end{array}$ \\
\hline $\begin{array}{l}\text { Identify the } \\
\text { requirement and } \\
\text { constraints in the } \\
\text { design of the } \\
\text { system }\end{array}$ & $\begin{array}{l}\text { Include analysis on the } \\
\text { needs of customer and } \\
\text { end-users. Engineering } \\
\text { specifications and } \\
\text { realistic constraints are } \\
\text { completely listed. }\end{array}$ & $\begin{array}{l}\text { The essential needs of } \\
\text { customer and end- } \\
\text { users are included. } \\
\text { The engineering and } \\
\text { realistic constraints } \\
\text { are listed but not } \\
\text { completely. }\end{array}$ & $\begin{array}{l}\text { The needs of customer } \\
\text { and end-users are not } \\
\text { considered. The } \\
\text { engineering and } \\
\text { realistic constraints are } \\
\text { not specified. }\end{array}$ \\
\hline $\begin{array}{l}\text { Application of the } \\
\text { detailed processes } \\
\text { and skills in } \\
\text { design }\end{array}$ & $\begin{array}{l}\text { Apply effectively the } \\
\text { engineering design } \\
\text { process, explore the } \\
\text { alternative design } \\
\text { options, evaluate the } \\
\text { design alternatives, } \\
\text { identify and choose the } \\
\text { final design. }\end{array}$ & $\begin{array}{l}\text { May not address one } \\
\text { of the following } \\
\text { items: engineering } \\
\text { design process, } \\
\text { alternative designs, } \\
\text { evaluation of design } \\
\text { alternatives, and } \\
\text { identification of final } \\
\text { design. }\end{array}$ & $\begin{array}{l}\text { Many of the following } \\
\text { items are not included: } \\
\text { engineering design } \\
\text { process, alternative } \\
\text { designs, evaluation of } \\
\text { design alternatives, } \\
\text { and identification of } \\
\text { final design. }\end{array}$ \\
\hline $\begin{array}{l}\text { Finalize designs } \\
\text { based on the need, } \\
\text { constraints and } \\
\text { economic analyses }\end{array}$ & $\begin{array}{l}\text { Demonstrate effective } \\
\text { use of engineering and } \\
\text { economic analyses, } \\
\text { standards and codes to } \\
\text { satisfy design } \\
\text { objectives and real- } \\
\text { world constraints. }\end{array}$ & $\begin{array}{l}\text { May not include one } \\
\text { of the following } \\
\text { items: engineering } \\
\text { analysis, economic } \\
\text { analysis, standards } \\
\text { and codes. }\end{array}$ & $\begin{array}{l}\text { Do not include many } \\
\text { of the followings: } \\
\text { engineering analysis, } \\
\text { economic analysis, } \\
\text { standards and codes. }\end{array}$ \\
\hline
\end{tabular}

Performance Indicators and Rubric for Outcome (e): Identify, formulate and solve engineering problem 
Outcome (e): Identify, formulate and solve engineering problem

\begin{tabular}{|l|l|l|l|}
\hline & \multicolumn{1}{|c|}{ Excellent } & \multicolumn{1}{|c|}{ Satisfied } & \multicolumn{1}{|c|}{ Unsatisfied } \\
\hline $\begin{array}{l}\text { Identify problems in } \\
\text { engineering and } \\
\text { describe the } \\
\text { problems } \\
\text { professionally }\end{array}$ & $\begin{array}{l}\text { Identify the detailed } \\
\text { problem } \\
\text { requirements, all the } \\
\text { given variables and } \\
\text { the expected results. } \\
\text { Constraints are listed } \\
\text { for the design or } \\
\text { solution. }\end{array}$ & $\begin{array}{l}\text { Identify the major } \\
\text { problem } \\
\text { requirements, most of } \\
\text { the given variables } \\
\text { and the expected } \\
\text { results. Essential } \\
\text { constraints are listed. }\end{array}$ & $\begin{array}{l}\text { Cannot identify the } \\
\text { problem } \\
\text { requirements, given } \\
\text { and design variables, } \\
\text { constraints. }\end{array}$ \\
\hline $\begin{array}{l}\text { Formulate the } \\
\text { problems with } \\
\text { proper } \\
\text { mathematical, } \\
\text { science, and } \\
\text { engineering theories } \\
\text { and principles. }\end{array}$ & $\begin{array}{l}\text { Present the problems } \\
\text { in a mathematical } \\
\text { way and include the } \\
\text { application of science } \\
\text { and engineering } \\
\text { theories and } \\
\text { principles without } \\
\text { mistakes. }\end{array}$ & $\begin{array}{l}\text { Present the problems } \\
\text { in a mathematical } \\
\text { way combined with } \\
\text { science and } \\
\text { engineering theories } \\
\text { but may contain some } \\
\text { errors. }\end{array}$ & $\begin{array}{l}\text { Cannot present the } \\
\text { problems in a } \\
\text { mathematical way, } \\
\text { and the science and } \\
\text { engineering theories } \\
\text { are missing. }\end{array}$ \\
\hline $\begin{array}{l}\text { Solve the problem } \\
\text { by following the } \\
\text { right procedure and } \\
\text { justify the solution }\end{array}$ & $\begin{array}{l}\text { Effective apply the } \\
\text { engineering problem } \\
\text { solving procedure: } \\
\text { mathematical } \\
\text { modeling, solution } \\
\text { method, interpretation } \\
\text { of results }\end{array}$ & $\begin{array}{l}\text { Essentially apply the } \\
\text { engineering problem } \\
\text { solving procedure: } \\
\text { mathematical } \\
\text { modeling, solution } \\
\text { method, interpretation } \\
\text { of results }\end{array}$ & $\begin{array}{l}\text { Cannot follow } \\
\text { correctly the } \\
\text { engineering problem } \\
\text { solving procedures at } \\
\text { all. }\end{array}$ \\
\hline
\end{tabular}




\section{Appendix B}

\section{MEEN 4313 \\ DESIGN OF THERMAL SYSTEMS \\ FALL 2015 SURVEY}

Name:

Please complete the survey to the best of your knowledge.

\section{Topics}

Rate the following course topics in terms of their importance in your engineering career.

Rating: 1 not important, 5 very important

\begin{tabular}{|l|l|l|l|l|l|}
\hline \multicolumn{1}{|c|}{ Topic } & 1 & 2 & 3 & 4 & 5 \\
\hline Pumps, fans, compressors & & & & & \\
\hline Heat exchangers & & & & & \\
\hline Curve fitting & & & & & \\
\hline Properties & & & & & \\
\hline Mathematical modeling & & & & & \\
\hline Simulations & & & & & \\
\hline Solution methods & & & & & \\
\hline
\end{tabular}

\section{Course Outcomes}

Rate the degree to which you achieve the following outcomes.

Rating: 1 does not achieve, 5 achieve

\begin{tabular}{|l|l|l|l|l|l|}
\hline \multicolumn{1}{|c|}{ Outcomes } & 1 & 2 & 3 & 4 & 5 \\
\hline Select pumps, fans, etc. & & & & & \\
\hline Select heat exchangers & & & & & \\
\hline Perform curve fitting & & & & & \\
\hline $\begin{array}{l}\text { Compute thermodynamics } \\
\text { and transport properties }\end{array}$ & & & & & \\
\hline $\begin{array}{l}\text { Find solutions of non- } \\
\text { linear algebraic equations }\end{array}$ & & & & & \\
\hline $\begin{array}{l}\text { Model and simulate } \\
\text { thermal systems }\end{array}$ & & & & & \\
\hline
\end{tabular}




\section{Computer/Design Projects}

Rate the usefulness of computer and design project in understanding thermal systems.

Rating: 1 not useful, 5 very useful

\begin{tabular}{|l|l|l|l|l|l|}
\hline & 1 & 2 & 3 & 4 & 5 \\
\hline Computer Project \#1 & & & & & \\
\hline Computer Project \#2 & & & & & \\
\hline Design Project & & & & & \\
\hline
\end{tabular}

Software and Example Programs

Rate the usefulness of MathCAD/Excel in solving and simulating thermal systems.

Rating: 1 not useful, 5 very useful

\begin{tabular}{|l|l|l|l|l|l|}
\hline & 1 & 2 & 3 & 4 & 5 \\
\hline MathCAD example files & & & & & \\
\hline Excel example files & & & & & \\
\hline
\end{tabular}

